\title{
ASPECTOS DO DIREITO NA OBRA DE SANTO TOMÁS DE AQUINO
}

\author{
ASPECTS OF LAW IN THE WORK OF SAINT THOMAS AQUINAS
}

Victor Emanuel Vilela Barbuy*

\begin{abstract}
Resumo:
No presente artigo, procuramos demonstrar a importância e atualidade de Santo Tomás de Aquino e de sua obra, bem como analisar alguns aspectos de suas teorias sobre o Direito, especialmente a classificação da Lei, composta pela Lei Eterna, Lei Natural, Lei Divina e Lei Humana. Concluímos que Santo Tomás, que não é um jurista, mas um filósofo do Direito, contribuiu para a formação da concepção autêntica do Direito e da Justiça como nenhum outro jusfilósofo o fez.

Palavras-chave: Santo Tomás de Aquino. Direito. Lei. Direito Natural. Lei Eterna. Lei Natural. Lei Divina. Lei Humana.
\end{abstract}

\begin{abstract}
:
In this paper we seek to demonstrate the importance and contemporarity of Saint Thomas Aquinas and his work as well as to analyze some aspects of his theories about Law, specially the classification of the Law, composed of the Eternal Law, the Natural Law, the Divine Law and the Human Law. We conclude that Saint Thomas, who is not a jurist but a philosopher of Law, contributed to the formation of the authentic conception of Law and Justice as no other jusphilosopher did.
\end{abstract}

Keywords: Saint Thomas Aquinas. Law. Natural Law. Eternal Law. Divine Law. Human Law.

1. Importância e atualidade da obra de Santo Tomás de Aquino

Santo Tomás de Aquino é o maior teólogo, filósofo, jusfilósofo, sociólogo e pensador político de todos os tempos. Sua obra e seu pensamento, de impressionante rigor, coerência, profundidade e atualidade, marcam não apenas o apogeu da Filosofia Medieval Ocidental, da Filosofia Escolástica e da Filosofia Cristã, mas de toda a Filosofia. Com efeito, consoante observa o Professor Mário Curtis Giordani, o Doutor Angélico representa, ainda em nossos dias:

Pelo vigor de sua inteligência, pela solidez e amplitude de seu saber, pela profundeza de sua doutrina, pela sinceridade com que procurou a verdade, pela luminosa clareza com que expôs sua argumentação e pela admirável coerência

Bacharel em Direito pela Universidade Presbiteriana Mackenzie. Mestrando em Direito Civil, na subárea História do Direito, pela Faculdade de Direito da Universidade de São Paulo, sob orientação do Professor Ignacio María Poveda Velasco. 
com que formulou suas conclusões, uma fonte perene de inspiração para um vasto elenco de estudiosos que inclui principalmente teólogos, filósofos e juristas. ${ }^{1}$

No mesmo sentido, o Padre Leonel Franca, sacerdote, filósofo e historiador da Filosofia, ressalta que "sete séculos passaram por sobre a obra admirável do anjo das escolas - séculos de luta e de revoluções profundas no campo das ideias, e ela ainda hoje persiste viva, palpitante, imortal como a verdade", ${ }^{2}$ e Cornelio Fabro, filósofo, teólogo e sacerdote italiano, sublinha que "o tomismo autêntico - o de Santo Tomás - tem e terá sempre uma atualidade permanente", ${ }^{3}$ sendo que "a originalidade, a atualidade e, poderíamos dizer, a urgência da concepção tomista sobre o homem”, quiçá não se haja jamais “apresentado tão patente, inclusive tão salvífica para a Igreja e para o mundo contemporâneo, como hoje em dia". ${ }^{4}$ Ainda em tal diapasão, Francisco Elías de Tejada y Spínola, jusfilósofo, historiador do Direito e pensador político espanhol, um dos máximos expoentes do jusnaturalismo tomista no século XX, aduz que "São Tomás é o pensador mais atual na verdade perene de suas teses", 5 e o pensador francês Marcel Demongeot anota que o Aquinate, "longe de depender, em qualquer medida, de seu tempo e das instituições de sua época, parece se haver colocado, mais do que nenhum outro, sub specie aeternitas". 6

Demonstram a atualidade de Santo Tomás e do tomismo o crescente interesse pelo Aquinate e sua obra, demonstrado, por exemplo, pelo número de publicações relativas ao tomismo, que passou, nos últimos anos, de cerca de trezentas para mais de mil e quatrocentas por ano; pelas novas edições das obras do Doutor Angélico, como as recentes edições em russo (2006) e chinês (2008) da Suma Teológica, a reedição desta grande obra, em sessenta e um volumes, pela Cambridge University Press, em 2006, e, em dezesseis volumes, baseada na edição de 1964, com introdução geral de Santiago Ramírez, pela Biblioteca de Autores Cristianos (BAC), de Madri, iniciada em 2010 e ainda não concluída, sem falar na última edição brasileira, pelas Edições Loyola, entre os anos de 2001 e 2006; pelo surgimento, em todo o Mundo, de novas coleções de livros com acentuada marca tomista; pela fundação, em diversos países, sob o impulso da Società

1 GIORDANI, Mário Curtis. Tomás de Aquino e o direito romano. In: Estudos em homenagem ao Professor Caio Mário da Silva Pereira. Rio de Janeiro: Forense, 1984. p. 458.

2 FRANCA, S.J., Pe. Leonel. Noções de história da filosofia. 21. ed. Com nota bibliográfica Adicional e um Suplemento sobre $O$ pensamento filosófico no Brasil de hoje, pelo Pe. Henrique Vaz, S.J. Rio de Janeiro: Livraria Agir Editora, 1973. p. 114.

3 FABRO, Cornelio. Santo Tomás de Aquino: ontem, hoje e amanhã (entrevista concedida à revista Palabra, n. 103, Madri, março de 1974). In: Hora Presente, São Paulo, ano 6, n. 16, set. 1974. p. 248.

4 Id. Ibid., p. 249.

5 ELÍAS DE TEJADA, Francisco. Porque somos tomistas: da Teologia à Política (comunicação apresentada ao Convegno di Studi per la celebrazione di San Tommaso d'Aquino nel VII Centenario, realizado em Gênova em 1974). Hora Presente, São Paulo, a. 6, n. 16, set. 1974, p. 103.

6 DEMONGEOT, Marcel. Le meilleur régime politique selon Saint Thomas. Paris: André Blot, 1928. p. 181. 
Internazionale Tommaso d'Aquino (SITA), de diversas sociedades acadêmicas tomistas; pelo surgimento de novos movimentos intelectuais inspirados nos ensinamentos de Santo Tomás, e pela aplicação de novas tecnologias às humanidades, que tem tido no tomismo alguns de seus mais relevantes marcos, a exemplo da base de dados do Index Thomisticus, trabalho pioneiro em seu gênero.?

A Filosofia de Santo Tomás representa, sem dúvida alguma, o apogeu da Filosofia Escolástica e da Filosofia Perene, da Philosophia Perennis de que fala o filósofo, cientista e matemático alemão Gottfried Leibniz. Consoante faz salientar o historiador do Direito, jusfilósofo e filósofo francês Michel Villey, aqueles que ainda acreditarem que o Doutor Comum não é senão um representante do tão decantado quanto falso "obscurantismo medieval", do "dogmatismo", de uma maneira de pensar que haveria sido superada pela "ciência moderna", isto é, aqueles que ainda crerem naquilo a que o pensador inglês Martin Lings denomina "superstições modernas", 8 certamente mudarão sua forma de pensar a respeito dele assim que lerem sua obra. ${ }^{9}$ Tinha isto em conta o pensador patrício Luís Washington Vita, que jamais foi tomista, quando criticou o preconceito antiescolástico de Sílvio Romero e João Cruz Costa, que, segundo ele, poderiam fazer sua, com relação ao tomismo, a frase atribuída a Oswald de Andrade: "Não li e não gostei". ${ }^{10}$

O mais importante dentre todos os Doutores da Igreja, Santo Tomás de Aquino foi chamado por Leão XIII, na Encíclica Aeterni Patris, de 1879, "Príncipe e Mestre" de todos os Doutores escolásticos, entre os quais se eleva "a uma altura incomparável". ${ }^{11}$ A Aeterni Patris, com efeito, marca o início de um profundo e sólido renascimento do pensamento tomista, que atingiria o apogeu nos derradeiros anos do século XIX e, principalmente, nos albores do século XX, e que já fora previsto, em 1867, pelo filósofo, jurista, jusfilósofo e Doutor em Medicina José Soriano de Souza, Cavaleiro da Ordem Pontifícia de São Gregório Magno e futuro Lente Catedrático de Direito Público e Constitucional da Faculdade de Direito do Recife. Soriano de Souza, após haver afirmado que "todos os homens amantes dos sãos estudos filosóficos" lutavam para restaurar as doutrinas e o método tomista, cujo abandono fizera da "filosofia uma torre

7 A maior parte dessas informações, bem como algumas outras que igualmente comprovam a força do tomismo na hora presente, pode ser encontrada em: ALARCÓN, Enrique; FAITANIN, Paulo S. Caminhos da historiografia tomista. In ALARCÓN, Enrique (Coord.). Atualidade do tomismo. Colaboração de Paulo Faitanin. Rio de Janeiro: Sétimo Selo, 2008. p. XII-XIII.

$8 \quad$ LINGS, Martin. Sabedoria tradicional e superstições modernas. Trad. de Mateus Soares de Azevedo. São Paulo: Polar, 1998.

9 VILLEY, Michel. Filosofia do Direito: definições e fins do Direito: os meios do Direito. Prefácio de François Terré. Trad. de Márcia Valéria Martinez de Aguiar. Rev. téc. de Ari Solon. 2. ed. São Paulo: Martins Fontes, 2008. p. 114.

10 VITA, Luís Washington. À guisa de prefácio. In: CAMPOS, Fernando Arruda. Tomismo e neotomismo no Brasil. São Paulo: Editorial Grijalbo Ltda., 1968. p. 13.

11 LEÃO XIII. Encíclica Aeterni Patris. Disponível em: <http://www.vatican.va/holy_father/leo_xiii/ encyclicals/documents/hf_1-xiii_enc_04081879_aeterni-patris_it.html >.Acesso em: 19 ago. 2011. 
de Babel, e um campo de discussões estéreis e intermináveis", lembrando das diversas obras sobre Santo Tomás e o tomismo que se iam publicando em França, Itália, Alemanha e Espanha, bem como das traduções da obra do Aquinate que iam surgindo nas línguas vernáculas, e salientando a importância do trabalho que iam desempenhando no sentido da divulgação das doutrinas tomistas as revistas La Civiltà Cattolica, de Roma, e La Scienza e la Fede, de Nápoles, assim como o fato de que as escolas católicas e seminários europeus iam reabrindo suas portas ao tomismo, sustenta que "tudo enfim prenuncia a próxima restauração da grande filosofia cristã fundada por S. Tomás". ${ }^{12}$

Poderíamos citar, além daquelas de Leão XIII, diversas outras palavras de papas, em encíclicas e outros documentos pontifícios, antes e depois do Concílio Vaticano II, bem como trechos de diversos documentos deste, ${ }^{13}$ todos repletos de merecidos elogios à doutrina tomista e de recomendações de que esta deve ser seguida e reconhecendo no Aquinate o primeiro dentre os Doutores da Igreja, demonstrando, assim, que a posição desta a respeito do Angélico Doutor e de sua obra não se alterou de Leão XIII até a hora presente. Não o faremos, porém, para que este texto não se torne por demais fastidioso, citando tão somente o testemunho de mais dois papas, um emitido muito antes do Concílio Vaticano II e outro na época em que este ocorria. O primeiro é de São Pio X, no Motu proprio Doctoris Angelici, de 29 de junho de 1914:

Quando indicamos São Tomás como supremo guia da filosofia escolástica, é claro que, antes de mais nada, nos referíamos aos princípios por ele ensinados, que são os fundamentos sobre os quais tal filosofia repousa. De fato, assim como deve rejeitar-se a opinião de certos pensadores antigos que afirmam nada importar à verdade da fé que se tenha este ou aquele ponto de vista acerca das coisas criadas desde que se forme de Deus uma noção justa, pois o erro sobre a natureza das coisas gera um falso conhecimento de Deus - assim também devem ser rigorosamente observados os princípios filosóficos de São Tomás de Aquino, graças aos quais se estabelece uma ciência em pleno acordo com a fé (Contra Gentiles, II, 3 e 4), todos os erros de todos os tempos se refutam, se distingue com inteira certeza o que deve ser atribuído a Deus e só a Deus (Ibid., III; Sum. Theol., I, 12, 4; 54, I) e são enfim postas à melhor luz a diversidade e analogia de Deus e das suas obras,

12 SOUZA, José Soriano de. Compêndio de Filosofia ordenado segundo os princípios e método do Doutor Angélico, S. Tomás de Aquino. Recife: Tipografia da Esperança, 1867, p. XXXVI-XXXVII.

13 Vide: Decreto Optatam Totius, sobre a formação sacerdotal, de 28 de outubro de 1965. Disponível em: http://www.vatican.va/archive/hist_councils/ii_vatican_council/documents/vat-ii_decree_19651028_ optatam-totius_po.html. Acesso em 19 de agosto de 2011; Declaração Gravissimum Educationis, sobre a educação cristã, também datada de 28 de outubro de 1965. Disponível em: $<$ http://www.vatican.va/archive/ hist_councils/ii_vatican_council/documents/vat-ii_decl_19651028_gravissimum-educationis_po.html>. Acesso em: 19 ago. 2011. 
diversidade e analogia expressas nestes termos pelo Quarto Concílio de Latrão: - "Entre o Criador e a criatura, não se pode assinalar tal semelhança que não se lhes marque ainda uma dessemelhança maior". Esses princípios de São Tomás, na sua generalidade e no seu conjunto, nada contêm, aliás, senão o que os melhores filósofos e os Príncipes e Doutores da Igreja haviam descoberto nas suas meditações e raciocínios, tanto sobre os caracteres próprios do humano conhecimento, como sobre a natureza de Deus e dos outros seres, como da ordem moral e do fim último da vida.

Nem a reta razão permite que se despreze nem a religião suporta que em nenhum aspecto seja diminuído um tão magnífico patrimônio de sabedoria, que São Tomás, depois de o ter recebido dos Antigos, aperfeiçoou e aumentou pelo poder do seu gênio quase digno dos Anjos e empregou em ilustrar e propagar a Doutrina Sagrada nas inteligências humanas (In Libr. Boethii De Trinit., q. 2, a. 3). ${ }^{14}$

Um pouco mais adiante, São Pio X, havendo sublinhado que, “depois da bem-aventurada morte do Santo Doutor, nunca a Igreja celebrou um Concílio a que Ele não assistisse com os tesouros da sua doutrina", assinala que:

A experiência de tantos séculos demonstrou, e torna-se dia a dia mais evidente, quanto era verdadeira essa afirmação do Nosso Predecessor João XXII - "Por si só, Tomás de Aquino iluminou mais a Igreja do que todos os outros Doutores; e nos seus livros aproveita-se mais durante um ano que durante uma vida inteira nos livros dos outros"15.

A última citação papal que faremos pertence a Paulo VI, constando da alocução por ele proferida na Pontifícia Universidade Gregoriana, em Roma, a 12 de março de 1964:

Tão intensa é a força intelectual do Doutor Angélico, tão sincero o seu amor pela verdade, tão grande a sua sabedoria ao investigar, demonstrar e unir devidamente as altíssimas verdades, que sua doutrina se torna meio muito eficaz, não só para estabelecer solidamente os fundamentos da fé, mas também para colher de modo útil e seguro os frutos do sadio progresso. ${ }^{16}$

Isto posto, faz-se mister assinalar que não é apenas entre os intelectuais, autoridades e sacerdotes católicos que é reconhecido o valor de Santo Tomás e de sua

14 PIO X. Motu proprio Doctoris Angelici. In: AMEAL, João. São Tomaz de Aquino: Iniciação ao estudo da sua figura e da sua obra. 3. ed., rev. e acresc., com novos apêndices e um quadro biobibliográfico. Porto: Livraria Tavares Martins, 1947. p. 484-485. Grifo nosso.

15 Id. Ibid., p. 486-487. Grifo nosso.

16 In Decreto Optatam Totius, nota 36. Disponível em: <http://www.universocatolico.com.br/index.php?/ decreto-optatam-totius.html>. Acesso em: 19 ago. 2011. 
doutrina. A título de exemplo, o pensador e escritor francês Gonzague Truc, agnóstico, não só reconheceu a importância do tomismo como proclamou que a "restauração do Espírito" somente se dará por meio de um retorno à Escolástica, ${ }^{17}$ e o jusfilósofo patrício Miguel Reale, que somente se tornou católico praticamente ao final da vida e que, filosoficamente, jamais foi tomista, reconheceu em Santo Tomás um "grande pensador", que, ao tratar da Lei e da Justiça, na Suma Teológica, "cuida, com admirável penetração, de problemas jurídico-políticos" ${ }^{\prime 18}$. Já dentre os inúmeros pensadores protestantes que reconheceram a importância da doutrina tomista, podemos mencionar, em primeiro lugar, Leibniz, que, no Discurso de Metafísica, de 1686, reconheceu "que os nossos modernos não fazem suficiente justiça a S. Tomás e a outros grandes homens desse tempo", isto é, do tempo da Escolástica, bem como que "há, nas opiniões dos filósofos e teólogos escolásticos, muito mais solidez do que se imagina", afirmando mesmo que estava persuadido de que:

Se algum espírito exato e meditativo se desse ao trabalho de esclarecer e digerir o pensamento deles [dos escolásticos] à maneira dos geômetras analíticos, encontraria aí um tesouro de grande quantidade de verdades importantíssimas e absolutamente demonstrativas. ${ }^{19}$

Outro pensador protestante, o jurista alemão Rudolf Von Jhering, na segunda edição do segundo volume de sua obra $A$ finalidade do Direito, assim observa a respeito do Doutor Angélico e de sua doutrina ético-jurídica:

Nesta presente segunda edição acrescento uma nota ao texto, graças à crítica que o Sr. Hohoff, Capelão em Häffe, consagrou à minha obra (no Literarischer Handweiser, sobretudo para a Alemanha católica, Münster, An. 23, n. 2), ao mesmo tempo que elucida com muitas e valiosas informações sobre a literatura concernente à moral católica. Prova-me ele, com citações de Tomás de Aquino, que este grande espírito já havia reconhecido, com perfeita exatidão, tanto o elemento realista, prático e social, como o histórico da moralidade. Censura-me, e com justiça, pela minha ignorância. Mas tal censura cabe, com muito mais razão, aos filósofos e teólogos protestantes, pouco cuidadosos de tirar partido dos pensamentos grandiosos de Tomás de Aquino. Com espanto a mim mesmo me pergunto como foi possível tivessem jamais podido cair em tão completo esquecimento, entre os nossos sábios protestantes, verdades como as professadas por ele! Quantos erros ter-se-iam evitado se tivessem elas sido fielmente guardadas! Quanto ao que me toca, talvez não tivesse escrito de todo o meu livro se as houvesse conhecido; pois, as ideias fundamentais

17 TRUC, Gonzague. Le retour à la Scolastique. Paris: La Renaissance du Livre, 1919. p. 162.

18 REALE, Miguel. Filosofia do direito. 1. ed. São Paulo: Edição Saraiva, 1953. v. 1, t. II., p. 547.

19 LEIBNIZ, Gottfried. Discurso de Metafísica. Trad. e notas de João Amado. Lisboa: Edições 70, 1995 . p. 30. 
que nele ia expor já se encontram, com perfeita clareza e notável fecundidade de concepção, expostas nas obras desse vigoroso pensador. ${ }^{20}$

Por fim, o filólogo clássico alemão Werner Jaeger, também protestante, observa, no opúsculo Humanismo e teologia, que:

\begin{abstract}
O período que assistiu ao erigir das catedrais e que fez nascer os tesouros da pintura e das esculturas medievais, não é de todo para nós uma época de barbárie, e o sistema filosófico de Santo Tomás nos parece, na sua arquitetura, como um edifício não menos impressionante que as catedrais de pedra construídas pelos mestres de obra de então. ${ }^{21}$
\end{abstract}

Importa ressaltar que concordamos com o Autor de Paideia não apenas no que tange ao Aquinate, mas também no que diz respeito à denominada Idade Média. Longe de ser a "idade das trevas" do mito iluminístico, representa ela, com efeito, um período de incomparável fecundidade, sobretudo nos campos da Teologia, da Filosofia, do Direito, da Literatura, da Pintura e da Arquitetura. Houvesse ela dado à luz tão somente as grandes Catedrais românicas, góticas e românico-góticas, as Universidades, a Cavalaria, a Suma Teológica de Santo Tomás e a Divina Comédia de Dante Alighieri, e, ainda assim, já poderíamos registrar tal período, no mínimo, como um dos mais gloriosos de toda a História.

A possante Cultura Medieval buscou - e de fato conseguiu - realizar o equilíbrio e a harmonia nas relações sociais e o equilíbrio e a harmonia nas relações entre o Poder Espiritual e o Poder Temporal. Como preleciona o jurista patrício Alfredo Buzaid, entre os séculos IX e XIII, edificou a Igreja as linhas básicas do pensamento, fundando-o no Primado da Religião e da Moral, a que podemos denominar, simplesmente, Primado do Espírito. Na Filosofia reinou "o mais elevado espiritualismo". ${ }^{22} \mathrm{Na}$ Economia, a organização corporativa ajustou as relações entre o capital e o trabalho, instituindo o salário justo ${ }^{23}$ e a concepção tomista da Propriedade, a um só tempo direito e dever individual e coletivo, dotado de caráter limitado e de alta função social e subordinado à Ética e ao Bem Comum, ordenado este ao fim último do Homem, promoveu o equilíbrio e a estabilidade social.

Politicamente, realizou a Idade Média a Monarquia Tradicional ${ }^{24}$, também denominada Monarquia Temperada ou Regime Misto, chamada Monarquia

20 JHERING, Rudolf. Der Zweck im Recht. 2. ed .Leipzig: Breitkopf und Härtel, 1886. v. 2. p. 161. Apud CORRÊA, Alexandre. Concepção tomista do direito natural (1941). In: Id. Ensaios políticos e filosóficos. Prefácio de Ubiratan Macedo. São Paulo: Editora Convívio/EDUSP, 1984. p. 167.

21 JAEGER, Werner. Humanisme et théologie. Trad. francesa de H. D. Saffrey. Paris: Cerf, 1956, p. 19.

22 BUZAID, Alfredo. Camões e o Renascimento. São Paulo: Saraiva, 1984. p. 104.

23 Id. Ibid., p. 104-105.

24 A respeito da Monarquia Tradicional: ELÍAS DE TEJADA, Francisco. La monarquía tradicional. Madri: 
Aristodemocrática pelo pensador, poeta e doutrinador político patrício Arlindo Veiga dos Santos $^{25}$ e saudada por Santo Tomás de Aquino como a melhor dentre as formas de governo, ${ }^{26}$ e também repúblicas, como Veneza, fiéis à Tradição e ordenadas ao Bem Comum, se constituindo em sínteses da Monarquia, da Aristocracia e da Politeia. No campo jurídico, tal época viveu o apogeu da Doutrina do Direito Natural Tradicional, ou Clássico, que teve em Santo Tomás de Aquino, como adiante veremos, seu mais notável expositor. A Poesia, neste período, também esteve, como tudo, de acordo com os ditames do Primado do Espírito. A Divina Comédia, por exemplo, reflete profundamente a sólida concepção tomista do Universo e do Homem, sendo mesmo uma espécie de Suma Teológica em versos. E, por derradeiro, as torres das Igrejas e Catedrais góticas não são senão preces dirigidas a Deus em humilde contemplação ungida de Fé, como evoca o Cardeal Cerejeira. ${ }^{27}$

O século XIII, século de Santo Tomás, marca, sem dúvida alguma, o apogeu do denominado Medievo, se constituindo no ápice do período a que o Padre Leonel Franca denomina "renascença cristã". ${ }^{28}$ Ademais, o próprio período conhecido como "Renascimento" se iniciou na própria Idade Média e, naquilo que teve de positivo,

Ediciones Rialp, 1954; GAMBRA, Rafael. La monarquía social y representativa en el pensamiento tracional. Madri: Ediciones Rialp, 1954; SARDINHA, António. A teoria das cortes gerais. 2. ed. Lisboa: qp, 1975.

25 SANTOS, Arlindo Veiga dos. As raízes históricas do patrianovismo. São Paulo: Pátria-Nova, 1946. p. 28.

26 Em Do Governo dos Príncipes, tendo em vista tal forma de Monarquia, o Doutor Angélico pondera que a Monarquia, isto é, o governo justo de um só, é a melhor das formas de governo (AQUINO, Santo Tomás de. Do Governo dos Príncipes ao Rei de Cipro e do Governo dos Judeus à Duquesa de Brabante. 2. ed. Trad. de Arlindo Veiga dos Santos. Prefácio de Leonardo van Acker. São Paulo: Editora Anchieta S/A, 1946. p. 43), frisando que "as províncias e cidades governadas por um só rei, gozam de paz, florescem na justiça e alegram-se com a opulência" (Idem, p. 28). Ainda em tal obra, aduz o Aquinate que a Monarquia, ainda quando decaída, é a melhor das formas de governo (Idem, p. 41-42) e que o governo de um só se corrompe menos facilmente em tirania do que o governo de muitos (Idem, p. 42-43).

Também na Suma Teológica defende Santo Tomás a superioridade da Monarquia Temperada, ou Regime Misto:

"A respeito da boa constituição dos chefes de uma cidade ou nação, duas cousas devemos considerar. Uma, que todos tenham parte no governo; assim se conserva a paz do povo e todos amam e guardam um tal governo, como diz Aristóteles. A outra é relativa à espécie do regime ou à constituição dos governos. E tendo estes diversas espécies, como diz o Filósofo, as principais são as seguintes. A monarquia, onde o chefe único governa segundo o exige a virtude; a aristocracia, i. é, o governo dos melhores, na qual alguns poucos governam segundo também o exige a virtude. Ora, o governo melhor constituído, de qualquer cidade ou reino, é aquele onde há um só chefe, que governa segundo a exigência da virtude e é o superior de todos. E, dependentes dele, há outros que governam, também conforme a mesma exigência. Contudo esse governo pertence a todos, quer por poderem os chefes ser escolhidos dentre todos, quer também por serem eleitos por todos. Por onde, essa forma de governo é a melhor, quando combinada: monarquia, por ser só um o chefe; aristocracia, por muitos governarem conforme o exige a virtude; democracia i. é, governo do povo, por, deste, poderem ser eleitos os chefes e ao mesmo pertencer à eleição deles. (Idem. Summa Theologica. $1^{\mathrm{a}}$ parte da $2^{\mathrm{a}}$ parte, q. CV, art. $1^{\mathrm{o}}$, sol. Trad. de Alexandre Corrêa. Org. e dir. de Rovílio Costa e Luís Alberto de Boni. Porto Alegre: Escola Superior de Teologia São Lourenço de Brindes, Livraria Sulina Editora; Caxias do Sul: Universidade de Caxias do Sul, 1980, p. 1.902).

27 CEREJEIRA, Gonçalves. A Idade Média. Coimbra: Coimbra Editora, Limitada, 1936. p. 113.

28 FRANCA, S.J., Pe. Leonel. Noções de História da Filosofia, cit., p. 103. 
não foi senão "um ramo florido da árvore poderosa da cultura medieval", como diria o pensador sueco Johan Nordström. ${ }^{29}$ E, ademais, a absoluta maioria dos grandes homens do Renascimento foi, em verdade, composta de filhos espirituais da denominada Idade Média, ou, como diria o pensador, poeta e ensaísta Tasso da Silveira, "os mais poderosos criadores do Renascimento" foram, em verdade, "nada mais nada menos do que esplêndidas frutificações da alma medieva". ${ }^{30}$

Dentre esses pujantes criadores do chamado Renascimento que representam magníficos produtos do espírito medieval, podemos citar, por exemplo, o poeta português Luís Vaz de Camões, mestre de Os Lusíadas, que foi, antes e acima de tudo, conforme demonstra Alfredo Buzaid, em Camões e o Renascimento, "uma lídima expressão da cultura medieval", ${ }^{31}$ sendo que a quintessência do ideal camoniano se encontra no pensamento do Medievo, "cujo fio de continuidade defende e preserva, cujos méritos louva e cujo esplendor exalta em versos de beleza perene". ${ }^{32}$ Em outras palavras, como aduz João de Scantimburgo, em Interpretação de Camões à luz de Santo Tomás de Aquino, o poeta de Os Lusíadas, "católico de profunda convicção", não se afastou da doutrina tomista, ainda bastante forte no século XVI, sendo que a "filosofia, a concepção de vida que da adolescência à morte o levou pelos caminhos da poesia, entronca-se na grande árvore da Patrística, dos Doutores e teólogos da Igreja", produzindo "a maior epopeia de todas as literaturas, e a lírica das mais belas, dentre as que foram compostas pelo estro humano, ungido do aristotélico-tomismo", ainda que houvesse assimilado também o platonismo. ${ }^{33}$

O mesmo que dissemos de Camões podemos também dizer de Gil Vicente, o célebre poeta e comediógrafo português, que, consoante demonstra Francisco Elías de Tejada em significativo ensaio constante de sua obra Tradição Portuguesa, não foi senão um "epígono do medievo", ${ }^{34}$ e, consoante ressalta Tasso da Silveira em igualmente significativo ensaio constante da obra Gil Vicente e outros estudos portugueses, toda a "profunda significação de Gil Vicente" está em ter sido ele, em pleno Renascimento, uma afirmação integral da "alma lusa medieva, com a sua catolicidade intrínseca". ${ }^{35}$ E podemos dizer, do mesmo modo, que William Shakespeare, poeta e dramaturgo da

29 NORDSTRÖM, Johan. Moyen Âge et Renaissance. Trad. francesa de T. Haunnas. Paris: Stock, 1933. p. 8.

30 SILVEIRA, Tasso da Silveira. Gil Vicente. In: Idem. Gil Vicente e outros estudos portugueses. São Paulo: Sociedade Editora Panorama, 1940. p. 27.

31 BUZAID, Alfredo. Camões e o Renascimento. São Paulo: Saraiva, 1984. p. 112.

32 Id. Ibid., p. 110.

33 SCANTIMBURgO, João de. Interpretação de Camões à luz de Santo Tomás de Aquino. São Paulo: Edições Melhoramentos; Secretaria da Cultura, Ciência e Teconologia do Estado de São Paulo; Editora da Universidade de São Paulo (EDUSP), 1978. p. 19

34 ELÍAS de Tejada, Francisco. Gil Vicente, epígono del medievo. In: Idem. La tradición portuguesa: los Orígenes (1140-1521). Madri: Fundación Francisco Elías de Tejada y Erasmo Pèrcopo e Editorial ACTAS, s.1., 1999. p. 235-265.

35 SILVEIRA, Tasso da. Gil Vicente, cit., p. 21. 
Inglaterra Elizabetana, como demonstra Cláudio de Cicco, “era tomista mesmo sem se dar conta disso", ${ }^{36}$ ou seja, era também um epígono do Medievo, ainda que não o soubesse.

Isto posto, voltemos a tratar de Santo Tomás e passemos a salientar alguns elementos de sua doutrina que reputamos particularmente positivos e relevantes.

Como bem observa Michel Villey, o gênio de Santo Tomás consiste, antes e acima de tudo, em superar e integrar, em uma visão integral do Mundo, a sabedoria cristã e a sabedoria pagã, que não são incompatíveis, posto que ambas, a Revelação e a mais elevada Filosofia alcançada pela cultura pagã, emanam da mesma fonte divina. ${ }^{37}$ O Santo Doutor fez isto não somente com o pensamento grego, especialmente com relação à Filosofia, e com o pensamento romano, particularmente no que diz respeito à Jurisprudência, mas também com o pensamento árabe e hebraico, de sorte que, consoante assinala o filósofo e historiador da Filosofia italiano Umberto Padovani, "representa a síntese crítica do pensamento clássico e cristão, hebraico e árabe" ${ }^{38}$ Em outras palavras, a doutrina de Santo Tomás se constitui na perfeita síntese de tudo aquilo de nobre e elevado que havia sido produzido por seus antecessores no campo do pensamento.

O que caracteriza a obra tomista é a "verdade integral", "verdade integral, cujos elementos procura por toda a parte", na expressão do filósofo francês Sertillanges. ${ }^{39}$ Como aduz o pensador e historiador português João Ameal, é justamente "esta busca apaixonada, fidelíssima, da verdade integral que comunica ao pensamento de $\mathrm{S}$. Tomás de Aquino a sua actualidade - derivada da sua perenidade". ${ }^{40}$

No plano sociológico, podemos afirmar, com Sertillanges, que foi o Doutor Angélico o verdadeiro descobridor da "física social":

Augusto Comte não descobriu a física social; só lhe exagerou o valor, arrastando-a ao determinismo. Os seus sucessores, os sociólogos, também não inventaram a ciência dos costumes nem a arte moral, que é uma aplicação daquela: Tudo isto está indicado em nosso Autor [Santo Tomás], em termos bem nítidos. ${ }^{41}$

No mesmo sentido, João Ameal, havendo salientado que Santo Tomás de Aquino é "o maior dos teólogos e filósofos de todos os tempos - cujo monumento adquiriu o título universalmente aceite de philosophia perennis", sendo o Doutor Comum o "herdeiro e valorizador de toda a sabedoria aristotélica e o definitivo orientador de todo

36 CICCO, Cláudio de. A visão sócio-política de William Shakespeare. Hora Presente, São Paulo, a. VI, n. 17, dez. 1974. p. 194.

37 VILLEY, Michel. Filosofia do direito: definições e fins do direito: os meios do direito, cit., p. 117.

38 PADOVANI, Humberto e CASTAGNOLA, Luís. História da filosofia. 3. ed. São Paulo: Melhoramentos, 1958. p. 179.

39 SERTILlangeS, A. D. Santo Tomás de Aquino. T. II. Trad. castelhana de José Luis de Izquierdo Hernández. Buenos Aires: Ediciones Desclée de Brouwer, 1946. p. 336.

40 AMEAL, João. Os novos horizontes da Sociologia. Integralismo lusitano: estudos portugueses, Lisboa, v. I, fasc. I, abr. 1932. p. 38.

41 SERTILlANGES, A. D. La philosophie morale de Saint Thomas. Paris: Librairie Félix Alcan, 1916. p. 10-11. 
o renascimento intelectual moderno", pondera que é ele "o sociólogo mais completo e mais actual que pode encontrar a nossa sede de verdade". ${ }^{42}$

O método sociológico tomista é, como demonstra o Autor de São Tomás de Aquino e de História de Portugal, o método empírico-racional, que é o "mais eficaz e o mais completo", concedendo à Razão, em integral acordo com a Fé, "um papel essencial no estudo das sociedades e na determinação dos seus valores morais dirigentes", ${ }^{43}$ mas exigindo, "ao serviço da razão, a maior soma de observações", considerando a política "obra de prudência e de experiência". ${ }^{44} \mathrm{O}$ método empírico-racional, dando à indução e à dedução o seu justo lugar, completa-as uma pela outra e de ambas se serve "no único desígnio de atingir a verdade" ${ }^{45}$ Assentada sobre os "eternos princípios morais da natureza humana" 46 , tem a Sociologia Tomista, segundo anota o sacerdote e pensador belga Simon Deploige, em primeiro lugar, o fato de que os moralistas e legisladores não devem se guiar pelas sugestões da fantasia, mas sim pelas tendências espontâneas do ser, inspirando-se na intrínseca finalidade das instituições, e, em segundo lugar, a necessidade de se atender às contingências e de sujeitar os preceitos morais e jurídicos à variabilidade das situações. ${ }^{47}$

Também é de impressionante valor e atualidade o pensamento político de Santo Tomás, condensado, particularmente, no Comentário à Política de Aristóteles, nos tratados Da lei e Do direito e da justiça da Suma Teológica e no opúsculo Do governo dos príncipes, também conhecido como De Regno. Como salienta o pensador e escritor francês Bernard Roland-Gosselin, empregando o termo "católico" no sentido de "universal", "os princípios da política tomista são católicos, quer dizer, válidos para todos os tempos e lugares". 48

Dentre os pontos centrais do pensamento político tomista, podemos destacar, além da concepção de Regime Misto, a que já fizemos referência no presente trabalho, a noção de Bem Comum, que é o bem de todos e de cada um, ${ }^{49}$ a concepção da Sociedade - e, por analogia, do Estado - como um meio a serviço do Bem Comum, ${ }^{50}$ a

42 AMEAL, João. Os novos horizontes da Sociologia, cit., p. 36.

43 Idem. A sociologia tomista: I - Método empírico-racional. Integralismo Lusitano: Estudos Portugueses, Lisboa, v. I, fasc. III, jun. 1932. p. 133.

44 ROLAND-GOSSELIN, Bernard. La doctrine politique de Saint Thomas. Paris: Marcel Rivière et Cie., 1928, p. XI. Apud AMEAL, João. A sociologia tomista: I - Método empírico-racional, cit., loc. cit.

45 AMEAL, João. A sociologia tomista: II - Regras fundamentais. Integralismo Lusitano: Estudos Portugueses, Lisboa, v. I, fasc. V, ago. 1932. p. 243.

46 Idem. A sociologia tomista: I - Método empírico-racional, cit., p. 135.

47 Cf. AMEAL, João. A sociologia tomista: II - regras fundamentais, cit., p. loc. cit.

48 ROLAND-GOSSELIN, Bernard. La doctrine politique de Saint Thomas d'Aquin, cit., p. 164. Apud AMEAL, João. Os novos horizontes da Sociologia, cit., p. 38.

49 AQUINO, Santo Tomás de. Do governo dos príncipes. Livro I, Cap. XV. In: Idem. Do governo dos príncipes ao Rei de Cipro e Do governo dos judeus à Duquesa de Brabante. 2. ed. Trad. e anotações de Arlindo Veiga dos Santos. Prefácio de Leonardo Van Acker. São Paulo: Editora Anchieta S/A, 1946, p. 101-102; SANTOS, Arlindo Veiga dos (Org.). Filosofia política de Santo Tomás de Aquino. 3. ed. melhorada. Prefácio do Prof. Dr. L. Van Acker. São Paulo: José Bushatsky, Editor, 1954. p. 143 e 149.

50 Idem. Livro I, Cap. XIV. In Idem. Do governo dos príncipes ao Rei de Cipro e Do governo dos judeus à 
definição dos governos justos como sendo aqueles ordenados ao Bem Comum e injustos aqueles ordenados ao bem privado do regente ou dos regentes, ${ }^{51}$ bem como a questão da resistência à tirania, que inclui, em determinados casos, o direito à revolução. ${ }^{52}$

São de manifesta relevância e atualidade, ainda, as teorias sócio-econômicas de Santo Tomás, pai do autêntico conceito de Função Social da Propriedade e da autêntica Doutrina Social da Igreja, que definiu claramente que o domínio sobre os bens, as coisas exteriores, que Deus concedeu aos homens, deve estar sempre subordinado a um fim, que impõe a necessidade racional e social do bom uso de tais bens. ${ }^{53}$ Entende, ademais, que, quanto ao uso de tais coisas, não deve a pessoa humana tê-las "como próprias, mas, como comuns, de modo que cada um as comunique facilmente aos outros, quando delas tiverem necessidade". 54

2. Aspectos do pensamento jurídico de Santo Tomás de Aquino

Como assinala Mário Curtis Giordani, embora não tendo sido um jurista nem tido a formação que caberia a um jurista, Santo Tomás foi um filósofo do Direito, ocupando mesmo "lugar de relevo na História da Filosofia do Direito". ${ }^{55}$ Nós outros, por nossa vez, afirmamos não só que o Angélico Doutor ocupa lugar de destaque na história do pensamento jusfilosófico, mas que representa o maior dentre todos os filósofos do Direito, posto que nenhum outro teólogo, filósofo ou jusfilósofo jamais formulou tão magnífica doutrina a respeito da Justiça, da Lei, do Direito Natural e do Direito Positivo quanto o Príncipe dos Doutores da Igreja. Assim, concordamos com o jurista francês Léon Duguit, quando este proclama que "a análise do sentimento de justiça foi feita por Santo Tomás de Aquino em termos nunca depois ultrapassados", ${ }^{56}$ do mesmo modo que concordamos com o jurista patrício Rubens Limongi França, quando este afirma que foi na Escolástica, com o pensamento de Santo Tomás, que o Direito Natural atingiu desenvolvimento cujas noções foram capazes de resistir até a hora presente, se constituindo nas colunas sobre as quais foi possível "edificar uma ciência jurídica que, sem perder de vista a realidade externa

Duquesa de Brabante, cit., p. 95-97; SANTOS, Arlindo Veiga dos (Org.). Filosofia política de Santo Tomás de Aquino, cit., p. 134-136 e 140-141.

51 Idem. Livro I, Cap. I. In Idem. Do governo dos príncipes ao Rei de Cipro e Do governo dos judeus à Duquesa de Brabante, cit., p. 20-21; SANTOS, Arlindo Veiga dos (Org.). Filosofia política de Santo Tomás de Aquino, cit., p. 29-30 e 35-36.

52 Idem. Livro I, Cap. VI. In Idem. Do governo dos príncipes ao Rei de Cipro e Do governo dos judeus à Duquesa de Brabante, cit., pp. 45-53; SANTOS, Arlindo Veiga dos (Org.). Filosofia política de Santo Tomás de Aquino, cit., p. 67-79.

53 Cf. ARIAS, Gino. Manual de Economía Política. Buenos Aires: L. Lajouane \& Cia. - Editores, 1942. p. 256.

${ }^{54}$ AQUINO, S. Tomás de. Suma Teológica. II. $^{a}$ parte da II. ${ }^{a}$ parte, q.66, art. $2^{\circ}$. Trad. de Alenxandre Corrêa. $1^{a}$ ed. Vol. XIV. São Paulo: Livraria Editora Odeon, 1937, p. 162.

55 GIORDANI, Mário Curtis. Tomás de Aquino e o Direito Romano, cit., pp. 482-483.

56 DUGUIT, Léon. Traité de droit constitutionnel. $3^{\mathrm{a}}$ ed. Tom. I. Paris: E. de Boccard, 1927, p. 122. 
dos fatos, não fizesse abstração dos juízos de valor, propiciando assim a restauração da concepção integral, e, por isso mesmo, realista e verdadeiramente científica do Direito", ${ }^{57}$

O pensamento jusnaturalista clássico, ou tradicional, que se assenta na tradição constituída pelos filósofos da Hélade, pelos jurisconsultos romanos e pelos teólogos e canonistas da Cristandade, tem o seu inegável apogeu na obra do Aquinate, tão ou mais viva e necessária hoje do que na Europa da décima terceira centúria.

O Direito Natural, que tem seu fundamento metafísico último em Deus, o Sumo Bem, Princípio e Fim de todas as coisas, repousa em um critério objetivo de justiça, se constituindo em um conjunto de normas inatas na natureza humana, pelas quais o homem se dirige, com o objetivo de agir retamente. Como preleciona o Professor Alexandre Corrêa, a razão conhece os preceitos do Direito Natural, intuitivamente, sendo ele, neste sentido, racional. Porém, consoante faz salientar o eminente jurista, pensador e jusfilósofo patrício, depende o Direito Natural, "no travejamento dos seus princípios, dos dados que ministra a experiência e, como tal, é experimental". ${ }^{58}$

O Direito Natural se divide em duas partes, uma universal e imutável e a outra variável. ${ }^{59}$ A primeira parte diz respeito aos primeiros princípios da Lei Natural, isto é, aos denominados princípios sinderéticos, ou seja, apreendidos pela Sindérese, ${ }^{60}$ expressão que designa o hábito intelectual dos primeiros princípios de ordem prática. Tais princípios podem ser reduzidos ao princípio segundo o qual devemos fazer o bem e evitar o mal. ${ }^{61}$ Já a segunda parte atine aos princípios secundários do Direito Natural, que derivam dos primeiros princípios, expressando suas necessidades imediatas. ${ }^{62}$

Para o Aquinate, Deus, Criador e Regedor do Universo, dirige o homem por meio de sua Providência, o instruindo pela Lei. Esta se divide em Lei Eterna, Lei Natural, Lei Divina Positiva e Lei Humana Positiva, ou, simplesmente, Lei Humana, que é a ordenação da razão para o Bem Comum, promulgada por aquele que tem o encargo da comunidade perfeita.

57 FRANÇA, R. Limongi. Direito Natural e Direito Positivo. In Revista da Universidade Católica de São Paulo, vol. XXII, fasc. 39, São Paulo, setembro de 1961, p. 264-265. Termos em negrito, no original.

58 CORRÊA, Alexandre. Há um Direito Natural? Qual o seu conteúdo? (1914). In: Idem. Ensaios políticos e filosóficos. Prefácio de Ubiratan Macedo. São Paulo: Editora Convívio/EDUSP, 1984. p. 36.

59 Idem, loc. cit; SOUSA, José Pedro Galvão de; GARCIA, Clovis Lema; CARVALHO, José Fraga Teixeira de. Dicionário de política. São Paulo: T.A. Queiroz, 1998. p. 180.

60 DERISI, D. Octavio Nicolás. Los fundamentos morales del derecho y del estado. Derecho natural. Derecho de gentes y derecho positivo. In: SOUSA, José Pedro Galvão de (Org.). O estado de direito. São Paulo: Editora Revista dos Tribunais. p. 60-61; SOUSA, José Pedro Galvão de; GARCIA, Clovis Lema; CARVAlHO, José Fraga Teixeira de. Dicionário de política, cit., loc. cit.

61 CORRÊA, Alexandre. Concepção tomista do Direito Natural (1941). In: Idem. Ensaios politicos e filosóficos, cit., p. 154; SOUSA, José Pedro Galvão de; GARCIA, Clovis Lema; CARVALHO, José Fraga Teixeira de. Dicionário de política, cit., loc. cit.

62 DERISI, D. Octavio Nicolás. op cit., p. 61-64; SOUSA, José Pedro Galvão de; GARCIA, Clovis Lema; CARVAlHO, José Fraga Teixeira de. Dicionário de Política, cit., loc. cit. 
A Lei Eterna, cuja existência é demonstrada pelo Doutor Comum na Suma Teológica, ${ }^{63}$ nada mais é que a razão da divina sabedoria enquanto rege o Universo, dirigindo todos os atos e movimentos.

A Lei Natural, por seu turno, é a participação da Lei Eterna na criatura racional. Isto porque, consoante preleciona o Aquinate, "entre todas as criaturas, a racional está sujeita à Divina Providência de modo mais excelente”, posto que participa ela própria da Providência, provendo a si e às demais.

Portanto participa [o ente humano] da razão eterna, donde tira a sua inclinação natural para o acto e o fim devidos. E a essa participação da lei eterna pela criatura racional se dá o nome de lei natural. Por isso, depois do Salmista ter dito Sacrificai sacrifício de justiça - continua, para como que responder aos que perguntam quais sejam as obras da justiça: Muitos dizem - quem nos patenteará os bens? A cuja pergunta dá a resposta: Gravado está, Senhor, sobre nós o lume do teu rosto, querendo assim dizer que o lume da razão natural, pelo qual discernimos o bem e o mal, e que pertence à lei natural, não é senão a impressão em nós do lume divino. Por onde é claro, que a lei natural não é mais do que a participação da lei eterna pela criatura racional. ${ }^{64}$

Isto posto, cumpre ressaltar que a existência da Lei Natural, fundamentadora do Direito Natural, fora reconhecida já na Antiguidade. Aristóteles, com efeito, assim afirma, na Retórica:

\begin{abstract}
É bastante cabível agora efetuar uma completa classificação das ações justas e injustas. Principiemos por observar que ações justas e injustas foram definidas relativamente a dois tipos de direito, além de o ser relativamente a duas classes de pessoas. Quando falo de dois tipos de direito ou leis, refirome à lei particular e à lei comum. A primeira varia segundo cada povo e é aplicável aos membros de cada povo, sendo parcialmente escrita, parcialmente não escrita; a lei comum é a lei natural, visto que há, de fato, uma justiça e uma injustiça das quais todos têm, de alguma maneira, a intuição, e que são naturalmente comuns a todos, independentemente de todo Estado e de toda convenção recíproca. É isso que a Antígona de Sófocles expressa com clareza ao declarar que o sepultamento de Polinices fora um ato justo, a despeito da proibição; ela quer dizer que fora um ato justo por ser o direito natural... ${ }^{65}$
\end{abstract}

63 AQUINO, Santo Tomás de. Suma teológica. $1^{\mathrm{a}}$ parte da $2^{\mathrm{a}}$ parte, q. XCI, art. I. 2. ed. v. 4. Trad. de Alexandre Corrêa. Org. e dir. de Rovílio Costa e Luís Alberto de Boni. Porto Alegre: Escola Superior de Teologia São Lourenço de Brindes, Livraria Sulina Editora; Caxias do Sul: Universidade de Caxias do Sul, 1980. p. 1.737 .

$64 \quad$ Id. $1^{\mathrm{a}}$ parte da $2^{\mathrm{a}}$ parte, q. XCI, art. II. op. cit., p. 1738.

65 ARISTÓTELES. Retórica. I, 13. Trad., textos adicionais e notas de Edson Bini. 1. ed. São Paulo: Edipro, 2011. p. 105. 
Mais tarde, em Roma, Cícero assim se exprimiria, na obra De Legibus:

Se a vontade dos povos, os decretos dos príncipes, as sentenças dos juízes, constituíssem o direito, seriam então de direito o latrocínio, o adultério, a falsificação dos testamentos, desde que aprovados pelo sufrágio e beneplácito das multidões.

Se fosse tão grande o poder das sentenças e das ordens dos insensatos, que chegassem estes ao ponto de alterar, com suas deliberações, a natureza das coisas, por que motivo não poderiam os mesmos decidir que o que é mau e pernicioso se considerasse bom e salutar? Ou por que motivo a lei, podendo transformar algo injusto em direito, não poderia do mesmo modo transformar o mal em bem? É que, para distinguir a lei boa da má, outra norma não temos senão aquela da natureza. Não apenas o justo e o injusto são discernidos pela natureza, mas também tudo o que é honesto e o que é torpe. Esta nos deu, assim, um senso comum, por ela insculpido em nosso espírito, para que identifiquemos a honestidade com a virtude e a torpeza com o vício.

Pensar que isso depende da opinião de cada um, e não da natureza, é coisa de louco. ${ }^{66}$

Quanto à Lei Divina Positiva, é aquela que o próprio Deus promulga por meio de uma intervenção direta na História. É o caso do Decálogo, que Deus confiou a Moisés, e da Lei do Evangelho, ou Lei de Cristo.

A necessidade da Lei Divina Positiva decorre, segundo Santo Tomás, das razões seguintes:

I - Como é o ente humano ordenado "ao fim da beatitude eterna, excedente à capacidade natural das suas faculdades", é necessário que, "além da lei natural e humana, seja também dirigido ao seu fim por uma lei imposta por Deus";

II - o homem, cujo juízo é incerto, sobretudo no que diz respeito às coisas contingentes e particulares, para poder, sem dúvida nenhuma, "saber o que deve fazer e o que deve evitar", necessita dirigir "os seus actos próprios pela lei estabelecida por Deus, que sabe não poder errar";

III - não podendo a Lei Humana coibir e ordenar os atos internos da pessoa humana, é mister que, para isto, sobrevenha a Lei Divina Positiva;

IV - porque, como aduz Santo Agostinho, a Lei Humana não tem o poder de punir ou de proibir a totalidade das malfeitorias. Isto porque, caso desejasse eliminar todos os

${ }_{66}$ CÍCERO, Marcus Tullius. De Legibus. I, 43-45. Tradução do Autor. Disponível em: <http://www. thelatinlibrary.com/cicero/leg1.shtml\#16>. Acesso em: 20 ago. 2011. 
males, "haveria consequentemente de impedir muitos bens, impedindo assim a utilidade do bem comum, necessário ao comércio humano". Destarte, "a fim de nenhum mal poder ficar sem ser proibido e permanecer impune, é necessário sobrevir a lei divina, que proíbe todos os pecados"67.

Já a Lei Humana Positiva não é senão, como restou dito, a ordenação da razão para o Bem Comum, promulgada pela autoridade competente. Isto porque, segundo preleciona o Angélico Doutor, “assim como a razão especulativa, de princípios indemonstráveis e evidentes tira as conclusões das diversas ciências, cujo conhecimento não existe em nós naturalmente", sendo, porém, descobertos por obra da razão; assim também, "dos preceitos da lei natural, como de princípios gerais e indemonstráveis, necessariamente a razão humana há de proceder a certas disposições mais particulares". E tais disposições, descobertas pela razão humana, observadas as demais condições pertencentes à essência da Lei, denominam-se leis humanas. ${ }^{68}$

Cumpre assinalar que, segundo o Aquinate, as leis humanas devem ser conformes ao Direito Natural, não o violando em ponto algum, sob pena de iniquidade, e as leis iníquas não são leis, mas antes corrupções da lei, não podendo ter força para obrigar ninguém:

A lei escrita, assim como não dá força ao direito natural, assim não lhe pode diminuir nem tirar a força, pois, não pode a vontade do homem mudar-lhe a natureza. E, portanto, se a lei escrita contiver alguma disposição contrária ao direito natural, será injusta, nem tem força para obrigar. Pois o direito positivo se aplica quanto ao direito natural não importa que se proceda de um ou de outro modo, como já provamos [q. 57, art. 2, resp. à $2^{\mathrm{a}}$ objeção]. E, por isso, tais leis escritas não se chamam leis, mas, antes, corrupções da lei, como já dissemos [ $\mathrm{I}^{\mathrm{a}}$ parte da IIa a parte., q. 95, art. 2]. E, portanto, não se deve julgar de acordo com elas. ${ }^{69}$

O autêntico significado da Lei Humana Positiva foi bem definido por Santo Isidoro de Sevilha, no Livro V de suas Etimologias, em passagem citada pelo Aquinate na Suma Teológica: ${ }^{70}$

A lei deve ser honesta, justa, possível, de acordo com a natureza e os costumes pátrios, conveniente ao lugar e ao tempo, necessária, útil, expressa com clareza,

${ }_{67}$ AQUINO, Santo Tomás de. Suma Teológica. 1. parte da 2. parte, q. XCI, art. III. op. cit., p. 1.741.

68 Id. 1. parte da 2. parte,q. XCI, art. III. op. cit., p. 1739-1740.

${ }_{69}$ Id. Suma Teológica. II. ${ }^{a}$ parte da II. ${ }^{a}$ parte, q. 60, art. 5., resp. à primeira objeção. Tradução de Alexandre Corrêa. 1. ed. v. XIV. São Paulo: Livraria Editora Odeon, 1937. p. 71.

70 AQUINO, Santo Tomás de. Suma Teológica. 1. parte da 2. parte, q. XCV, art. IV. op. cit., p. 
de modo a não conter por obscuridade algo capcioso, escrita não para o interesse privado, mas para a utilidade comum dos cidadãos. ${ }^{71}$

Por derradeiro, é imperioso destacar que o Direito Natural por si só não basta como regra de vida, sendo necessária sua complementação pelo Direito Positivo. A este cabe a concretização dos princípios do Direito Natural, aplicando as máximas deste às particularidades da vida em Sociedade. E deve fazê-lo levando em conta as circunstâncias de tempo e de lugar, motivo pelo qual deve possuir caráter eminentemente histórico. ${ }^{72}$ Daí concordarmos com o Professor Alexandre Corrêa, quando este sustenta que as ideias da Escola Histórica, especialmente com a forma que lhe imprimiu o Conde Joseph De Maistre, "são admissíveis, como complemento à verdadeira teoria do Direito Natural". ${ }^{73}$

Seja esta a nossa humilde contribuição ao estudo da doutrina daquele que foi chamado, com justiça, pelo Cardeal Bessarion, "o mais santo dos sábios e o mais sábio dos santos". ${ }^{74}$ Que ela tenha, na falta de outros méritos, aquele de fazer com que mais pessoas, particularmente nos meios jurídicos, se interessem pela portentosa obra do Aquinate, de que não pudemos traçar senão um palidíssimo esboço. Como salienta o filósofo e historiador da Filosofia francês Étienne Gilson, a "infinita riqueza e maravilhosa organização" da doutrina tomista se revelam tão somente "no curso de um estudo direto", ${ }^{75} \mathrm{e}$, como ressalta Michel Villey, os juristas só teriam a ganhar caso se libertassem do preconceito que ainda envolve o nome e a obra do Angélico Doutor. ${ }^{76}$ Convidamos, pois, aqueles que ainda não conhecem a obra do magno Mestre da Escolástica para que, vencendo o preconceito que por ventura tiverem, se debrucem sobre ela. Aqueles que o fizerem nada perderão.

São Paulo, 22 de agosto de 2011.

\section{Referências}

ALARCÓN, Enrique; FAITANIN, Paulo S. Caminhos da historiografia tomista. In: LARCÓN, Enrique (Coord.). Atualidade do tomismo. Colaboração de Paulo Faitanin. Rio de Janeiro: Sétimo Selo, 2008. p. XI-XV.

71 ISIDORUS HISPALENSIS, Sanctus. Etymologiarum sive Originum. Liber V, XXI. Tradução do Autor. Disponível em: <http://www.thelatinlibrary.com/isidore/5.shtml>. Acesso em: 20 ago. 2011.

72 Neste sentido: SOUSA, José Pedro Galvão de; GARCIA, Clovis Lema; CARVALHO, José Fraga Teixeira de. Dicionário de Política, cit., p. 179.

73 CORRÊA, Alexandre. Há um Direito Natural? Qual o seu conteúdo? (1914), cit., p. 42.

74 BESSARION, Johannes. Adversus calumniatorem Platonis. L.2 c.7 Apud BERTHIER, O. P., J. Sanctus Thomas Aquinas “Doctor communis” Ecclesiae. Roma: 1914, n. 679, p. 92.

75 GILSON, Étienne. A Filosofia na Idade Média. Trad. de Eduardo Brandão. São Paulo: Martins Fontes, 2001. p. 669.

76 VILLEY, Michel. Filosofia do direito: definições e fins do direito: os meios do Direito, cit., p. 114. 
AMEAL, João. São Tomaz de Aquino: Iniciação ao estudo da sua figura e da sua obra. 3 ed., rev. e acresc., com novos apêndices e um quadro biobibliográfico. Porto: Livraria Tavares Martins, 1947. . Os novos horizontes da Sociologia. Integralismo Lusitano: Estudos Portugueses, Lisboa, v. I, fasc. I, p. 29-38, abr. 1932. . A Sociologia Tomista: I - Método empírico-racional. Integralismo Lusitano: Estudos Portugueses, Lisboa, v. I, fasc. I, p. 126-136, abr. 1932. . A Sociologia Tomista: II - Regras fundamentais. Integralismo Lusitano: Estudos Portugueses, Lisboa, v. I, fasc. I, p. 243-24, abr. 1932.p. 243-249. . A revolução tomista. Braga: Livraria Cruz, 1952.

AQUINO, Santo Tomás de. Tomás de. Suma Teológica. 1. parte da 2. parte, q. XCI, art. I. 2. ed. Trad. de Alexandre Corrêa. Org. e dir. de Rovílio Costa e Luís Alberto de Boni. Porto Alegre: Escola Superior de Teologia São Lourenço de Brindes, Livraria Sulina Editora; Caxias do Sul: Universidade de Caxias do Sul, 1980. v. 4.

. Suma Teológica. II. ${ }^{\mathrm{a}}$ parte da II. ${ }^{\mathrm{a}}$ parte, q. 66, art. $2^{\circ}$. Trad. de Alenxandre Corrêa. 1. ed. v. XIV. São Paulo: Livraria Editora Odeon, 1937.

Do Governo dos Príncipes ao Rei de Cipro e do Governo dos Judeus à Duquesa de Brabante. 2. ed. Trad. de Arlindo Veiga dos Santos. Prefácio de Leonardo van Acker. São Paulo: Editora Anchieta S/A, 1946.

ARIAS, Gino. Manual de economía política. Buenos Aires: L. Lajouane \& Cia. - Editores, 1942.

ARISTÓTELES. Retórica. I, 13. Trad., textos adicionais e notas de Edson Bini. 1. ed. São Paulo: Edipro, 2011.

BARBUY, Heraldo. Sumo bem e suma riqueza. Separata do anuário da Faculdade de Filosofia Sedes Sapientiae da Universidade Católica de São Paulo,1953.

BERTHIER, O. P., J. Sanctus Thomas Aquinas “Doctor communis” Ecclesiae. Roma: 1914.

BUZAID, Alfredo. Camões e o renascimento. São Paulo: Saraiva, 1984.

CEREJEIRA, Gonçalves. A Idade Média. Coimbra: Coimbra Editora, Limitada, 1936.

CHeSterton, G. K. Santo Tomás de Aquino. Trad. e notas de Carlos Ancêde Nougué. São Paulo: Editora LTR, 2003.

CICCO, Cláudio de. A visão sócio-política de William Shakespeare. Hora Presente, São Paulo, a. VI, n. 17, p. 1-15, dez. 1974.

CÍCERO, Marcus Tullius. De Legibus. Liber I. Disponível em: <http://www.thelatinlibrary.com/ cicero/leg1.shtml\#16>. Acesso em: 20 ago. 2011. 
CONCÍLIO VATICANO II. Decreto Optatam Totius, sobre a formação sacerdotal, de 28 de outubro de 1965. Disponível em: <http://www.vatican.va/archive/hist_councils/ii_vatican_council/ documents/vat-ii_decree_19651028_optatam-totius_po.html>. Acesso em: 08 maio 2011.

- Declaração Gravissimum Educationis, sobre a educação cristã, também datada de 28 de outubro de 1965. Disponível em: <http://www.vatican.va/archive/hist_ councils/ii_vatican_council/documents/vat-ii_decl_19651028_gravissimum-educationis_po.html>. Acesso em: 08 maio 2011.

CORRÊA, Alexandre. Há um Direito Natural? Qual o seu conteúdo? (1914). In: . Ensaios políticos e filosóficos. Prefácio de Ubiratan Macedo. São Paulo: Editora Convívio/EDUSP, 1984. p. $5-43$.

. Concepção tomista do Direito Natural (1941). In . Ensaios políticos e filosóficos. Prefácio de Ubiratan Macedo. São Paulo: Editora Convívio/EDUSP, 1984. p. 141-250.

. S. Tomás e o regime da lei (1962). In: . Ensaios politicos e filosóficos. Prefácio de Ubiratan Macedo. São Paulo: Editora Convívio/EDUSP, 1984. p. 319-322.

DEMONGEOT, Marcel. Le meilleur régime politique selon Saint Thomas. Paris: André Blot, 1928.

DERISI, D. Octavio Nicolás. Los fundamentos Morales Del Derecho y Del Estado. Derecho Natural. Derecho de Gentes y Derecho Positivo. In: SOUSA, José Pedro Galvão de (Org.). O Estado de Direito. São Paulo: Editora Revista dos Tribunais. p. 37-70.

ELÍAS DE TEJADA, Francisco. Porque somos tomistas: da teologia à política (comunicação apresentada ao Convegno di Studi per la celebrazione di San Tommaso d'Aquino nel VII Centenario, realizado em Gênova em 1974). Hora Presente, São Paulo, a. VI, n. 16, p. 93-103, set. 1974.

. La Monarquía Tradicional. Madri: Ediciones Rialp, 1954.

. Gil Vicente, epígono del medievo. In: La tradición portuguesa:

los Orígenes (1140-1521). Madri: Fundación Francisco Elías de Tejada y Erasmo Pèrcopo e Editorial ACTAS, s.1., 1999. p. 235-265.

FABRO, Cornelio. Santo Tomás de Aquino: ontem, hoje e amanhã (entrevista concedida à revista Palabra, n. 103, Madri, março de 1974). Hora Presente, São Paulo, a. VI, n. 16, p. 246-254, set. 1974.

FINNIS, John. Lei natural e direitos naturais. Trad. de Leila Mendes. São Leopoldo: Editora UNISINOS, 2007.

. Direito natural em Tomás de Aquino. Trad. de Leandro Cordioli. Porto Alegre: Safe, 2007.

FRANCA, S.J., Pe. Leonel. Noções de história da filosofia. 21. ed. Com nota bibliográfica Adicional e um Suplemento sobre O pensamento filosófico no Brasil de hoje, pelo Pe. Henrique Vaz, S.J. Rio de Janeiro: Livraria Agir Editora, 1973. 
FRANÇA, R. Limongi. Direito natural e direito positivo. Revista da Universidade Católica de São Paulo, v. XXII, fasc. 39, São Paulo, p. 243-281, set. 1961.

GAMBRA, Rafael. La Monarquía social y representativa en el pensamiento tracional. Madri: Ediciones Rialp, 1954.

GILSON, Étienne. A filosofia na idade média. Trad. de Eduardo Brandão. São Paulo: Martins Fontes, 2001.

GIORDANI, Mário Curtis. Tomás de Aquino e o direito romano. In: VÁRIOS. Estudos em homenagem ao Professor Caio Mário da Silva Pereira. Rio de Janeiro: Forense, 1984.

HIRSCHBERGER, Johannes. História da filosofia na idade média. Trad. Alexandre Correia. São Paulo: Herder, 1966.

ISIDORUS HISPALENSIS, Sanctus. Etymologiarum sive Originum. Liber V, XXI. Disponível em: $<$ http://www.thelatinlibrary.com/isidore/5.shtml >. Acesso em: 20 ago. 2011.

JAEGER, Werner. Humanisme et théologie. Trad. francesa de H. D. Saffrey. Paris: Cerf, 1956.

LEÃO XIII. Encíclica Aeterni Patris. Disponível em: < http://www.vatican.va/holy_father/leo_xiii/ encyclicals/documents/hf_1-xiii_enc_04081879_aeterni-patris_it.html>. Acesso em: 08 maio 2011.

LEIBNIZ, Gottfried. Discurso de metafísica. Trad. e notas de João Amado. Lisboa: Edições 70, 1995.

LINGS, Martin. Sabedoria tradicional e superstições modernas. Trad. de Mateus Soares de Azevedo. São Paulo: Polar, 1998.

MANSER O.P., Dr. G. M. La esencia del tomismo. Trad. espanhola de Valentín García Yebra. Madri: Instituto "Luis Vives" de Filosofía, Consejo Superior de Investigaciones Científicas, 1947.

MARTÍNEZ Barrera, Jorge. A política em Aristóteles e Santo Tomás. Trad. e prefácio de Carlos Ancêde Nougué. Rio de Janeiro: Sétimo Selo, 2007.

PADOVANI, Humberto; CASTAGNOLA, Luís. História da filosofia. 3. ed. São Paulo: Melhoramentos, 1958.

PIO X. Motu proprio Doctoris Angelici. In: AMEAL, João. São Tomaz de Aquino: iniciação ao estudo da sua figura e da sua obra. 3 ed., rev. e acresc., com novos apêndices e um quadro biobibliográfico. Porto: Livraria Tavares Martins, 1947. p. 484-488.

NORDSTRÖM, Johan. Moyen Âge et Renaissance. Trad. francesa de T. Haunnas. Paris: Stock, 1933.

RAMÍREZ, O.P., Santiago. Introducción general. In: Suma teologica. Edição bilíngue. Texto latino da edição crítica leonina. Tradução castelhana e notas por uma comissão de padres dominicanos presidida por Fr. Francisco Barbado Viejo, O.P. Tomo I. Tratado de Dios Uno. Trad. castelhana de Francisco Muñiz, O.P. 1. edição na série BAC Thesaurus, baseada na edição de 1964. Madri: Biblioteca de Autores Cristianos (BAC), 2010. p. 2*-230*. 
REALE, Miguel. Filosofia do Direito. 1. ed. Tomo II. São Paulo: Edição Saraiva, 1953. v. 1.

SANTOS, Arlindo Veiga dos. As raízes históricas do Patrianovismo. São Paulo: Pátria-Nova, 1946. (Org.). Filosofia politica de Santo Tomás de Aquino. 3. ed. melhorada.

Prefácio do Prof. Dr. L. Van Acker. São Paulo: José Bushatsky, Editor, 1954.

SCANTIMBURGO, João de. Interpretação de Camões à luz de Santo Tomás de Aquino. São Paulo: Edições Melhoramentos; Secretaria da Cultura, Ciência e Teconologia do Estado de São Paulo; Editora da Universidade de São Paulo (EDUSP), 1978.

SERTILLANGES, A. D. La philosophie morale de Saint Thomas. Paris: Librairie Félix Alcan, 1916. . Santo Tomás de Aquino. T. II. Trad. castelhana de José Luis de Izquierdo Hernández. Buenos Aires: Ediciones Desclée de Brouwer, 1946.

SILVEIRA, Tasso da Silveira. Gil Vicente. In: . Gil Vicente e outros estudos portugueses. São Paulo: Sociedade Editora Panorama, 1940. p. 11-41.

SOUSA, José Pedro Galvão de. Direito natural, direito positivo e estado de direito. São Paulo: Editora Revista dos Tribunais, 1977. . A historicidade do direito e a elaboração legislativa. São Paulo:

Editora Franciscana, 1970.

CARVAlHO, José Fraga Teixeira de. Dicionário de politica. São Paulo: T.A. Queiroz, 1998.

TRUC, Gonzague. Le retour à la Scolastique. Paris: La Renaissance du Livre, 1919.

SOUZA, José Soriano de. Compêndio de Filosofia ordenado segundo os princípios e método do Doutor Angélico, S. Tomás de Aquino. Recife: Tipografia da Esperança, 1867.

VILLEY, Michel. Filosofia do direito: definições e fins do direito: os meios do direito. Prefácio de François Terré. Trad. de Márcia Valéria Martinez de Aguiar. Rev. téc. de Ari Solon. 2. ed. São Paulo: Martins Fontes, 2008.

. A formação do pensamento jurídico moderno. Trad. de Claudia Berliner. São Paulo: Martins Fontes, 2009.

VITA, Luís Washington. À guisa de prefácio. In: CAMPOS, Fernando Arruda. Tomismo e neotomismo no Brasil. São Paulo: Editorial Grijalbo Ltda., 1968. p. 13-16. 